Michał Romanowski

\title{
Ocena rządowego projektu ustawy o zmianie ustawy - Kodeks spółek handlowych oraz niektórych innych ustaw ${ }^{1}$
}

\begin{abstract}
Nie istnieje potrzeba wprowadzenia do Kodeksu spółek handlowych nowego typu spółki kapitałowej. Cele wskazywane przez projektodawcę mogą być osiągnięte w wyniku nieskomplikowanej reformy spółki z 0.o. Projekt wprowadza liczne rozwiązania w oderwaniu od rozwiązań funkcjonujących w spółce z o.o. i spółce akcyjnej w sposób prowadzący do destabilizacji i rozsadzenia systemu prawa spółek kapitałowych. Bez uzasadnienia merytorycznego wprowadzono zróżnicowane rozwiązania w tych samych kwestiach w prostej spółce akcyjnej oraz w spółce z o.o. i spółce akcyjnej.
\end{abstract}

Słowa kluczowe: Kodeks spółek handlowych, projekt ustawy, przedsiębiorczość

Assessment of the governmental Bill on Amending the Act - the Commercial Companies Code and Certain other Acts: There is no need to introduce a new type of capital company into the Commercial Companies Code. The objectives indicated by the sponsor of the bill can be achieved within the framework of a simple reform of the limited liability company. The bill introduces numerous solutions without taking into account solutions regardinglimited liability company and joint stock company, thus leading to the destabilization and disruption of the system of capital companies law. Without a substantive justification, differentiated solutions of the same issues were introduced with regard to simple joint-stock company, limited liability company and joint-stock company.

Keywords: Commercial Companies Code, bill, entrepreneurship

Profesor doktor hab., Instytut Prawa Cywilnego, Katedra Prawa Handlowego, kierownik Pracowni Prawa Rynku Kapitałowego, Wydział Prawa i Administracji Uniwersytetu

Warszawskiego - m.romanowski@romanowski.eu - https://orcid.org/0000-0003-4667-9082

\section{Wprowadzenie i zastrzeżenia}

1. Wprowadzenie do polskiego Kodeksu spółek handlowych nowego typu spółki kapitałowej pod nazwą prosta spółka akcyjna spotkało się z bardzo krytyczną oceną nie tylko polskiej nauki prawa handlowego, ale także organów doradczych Prezesa Rady Ministrów (Rady Legislacyjnej przy Prezesie Rady Ministrów) oraz Ministerstwa Sprawiedliwości. Zasadnicze zarzuty, jakie zostały zgłoszone wobec projektu wprowadzenia do polskiego prawa spółek prostej spółki akcyjnej, dotyczą:

1 Ocena projektu ustawy - o zmianie ustawy - Kodeks spółek handlowych oraz niektórych innych ustaw (druk nr 3236) sporządzona 12 marca 2019 r. na zlecenie zastępcy Szefa Kancelarii Sejmu; BAS 314/19. 
- wprowadzania do Kodeksu spółek handlowych nowego typu spółki kapitałowej, podczas gdy cele wskazywane przez projektodawcę mogą być osiągnięte w wyniku reformy (i to niezbyt skomplikowanej) spółki z ograniczoną odpowiedzialnością,

- wprowadzania wraz z prostą spółką akcyjną rozwiązań w oderwaniu od rozwiązań funkcjonujących w spółce z o.o. i spółce akcyjnej w sposób prowadzący do destabilizacji i rozsadzenia systemu prawa spółek kapitałowych; regulacja prostej spółki akcyjnej staje się swoistym „państwem w państwie prawa spółek kapitałowych“,

- przyjęcia metody stworzenia konstrukcji prostej spółki akcyjnej jako swoistego zlepku rozwiązań znanych spółce z o.o., spółce akcyjnej, spółkom osobowym oraz spółce europejskiej,

- doprowadzenia do sytuacji, w której bez uzasadnienia merytorycznego mamy zróżnicowane rozwiązania przyjmowane $\mathrm{w}$ tych samych kwestiach $\mathrm{w}$ prostej spółce akcyjnej oraz w spółce z o.o. i spółce akcyjnej,

- liczne błędy legislacyjne w odniesieniu do kwestii szczegółowych.

2. Ze względu na narzucone ograniczenia co do objętości niniejszej opinii, zasadniczą intencją jej napisania jest dokonanie oceny potrzeby i celu regulacji prostej spółki akcyjnej oraz przykładowe odniesienie się do tych rozwiązań w projekcie, które przedstawiane są jako kluczowe.

\section{Potrzeba i cel regulacji - uzasadnienie projektodawcy}

1. Przedmiotem projektu jest uregulowanie nowego typu spółki kapitałowej pod nazwą prosta spółka akcyjna (dalej: PSA). W uzasadnieniu projektu wskazano, że PSA ma być: nowoczesna forma niepublicznej spótki kapitałowej przeznaczona dla innowacyjnych przedsięwzięć. PSA ma łączyć korporacyjny charakter spótki jako osoby prawnej $z$ cecha podstawowa jaka jest wyłaczenie osobistej odpowiedzialności wspólników za zobowiązania spótki ze znaczną swobodą ksztaltowania stosunku spółki obejmująca relacje wewnętrzne między wspólnikami oraz system zarzadzania spótka i nadzór nad systemem zarządzania spółką. PSA ma wyróżniać od spółki z o.o. i spółki akcyjnej (s. 1 uzasadnienia projektu):

- dopuszczenie nowych kategorii wkładów na pokrycie obejmowanych praw członkowskich w postaci świadczenia pracy lub usług, oraz

- nowoczesny mechanizm ochrony wierzycieli spółki, odstępujący od konstrukcji kapitału zakładowego na rzecz elastycznych ograniczeń wypłat na rzecz akcjonariuszy, uwzględniających zarówno wielkość zadłużenia spółki, jak i stopień jej wypłacalności.

2. Projektodawca wskazuje (s. 3 uzasadnienia), że impulsem do prac nad PSA była analiza potrzeb startupów, które w odpowiednich warunkach (czytaj: w for- 
mie PSA) mogą: wygenerować w 2023 r. ponad 2,2 mld zł wartości dodanej [...] $i$ stworzyć ponad 50,3 tys. miejsc pracy, co przełoży się na przychody gospodarstw domowych na poziomie $757 \mathrm{mln} z$.

3. Projektodawca twierdzi, że projekt stanowi odpowiedź na oczekiwania środowisk związanych z działalnością typu startup, które wskazują na liczne problemy ograniczające rozwój startupów, takie jak: trudności w rozpoczynaniu działalności gospodarczej, trudności w pozyskiwaniu kapitału, trudności w likwidacji spółek w razie niepowodzenia przedsięwzięcia. Jako konkretne przykłady ilustrujące istnienie zgłaszanych trudności występujących w obowiązującym systemie prawa spółek wskazuje się:

- instytucję kapitału zakładowego, która ma poważnie utrudniać ukształtowanie relacji w spółce tak, aby pozycja wspólnika była powiązana nie tylko z jego wkładem majątkowym, ale także z jego osobistymi zdolnościami i pracą, czyli kapitałem ludzkim,

- ograniczenia uprzywilejowywania akcji i udziałów,

- skomplikowany charakter inwestycji w spółkę z o.o., wyrażający się w obowiązku zachowania formy pisemnej z podpisami notarialnie poświadczonymi przy zawieraniu umowy nabycia udziałów,

- brak inkorporowania udziałów w spółce z o.o. w dokumencie i w zapisie elektronicznym, czyli brak przyznania udziałom statusu papieru wartościowego,

- brak możliwości tworzenia udziałów niemych w spółce z o.o.,

- minimalną wartość udziału w spółce z o.o. na poziomie 50 zł, co ma ograniczać możliwości korzystania z rosnącego znaczenia pozyskiwania kapitału w drodze tzw. crowdfundingu (finansowanie społecznościowe),

- drogi i skomplikowany sposób zawiązania i prowadzenia spółki akcyjnej wyrażający się w wymogu protokołowania przez notariusza uchwał walnego zgromadzenia, obligatoryjnym badaniu rocznych sprawozdań finansowych przez biegłego rewidenta i wysokim kapitale zakładowym w wysokości 100 tys. zł, a de facto 25 tys. zł (tylko jedna czwarta kapitału zakładowego spółki akcyjnej musi być pokryta przed rejestracją spółki).

W konsekwencji projektodawca podnosi, że ani spółka z o.o., ani spółka akcyjna nie są w pełni odpowiednie do potrzeb „przynajmniej części innowacyjnych przedsięwzięć" (s. 5 uzasadnienia).

4. Projektodawca twierdzi, że PSA wprowadza nowatorskie rozwiązania na gruncie polskiego prawa spółek, które inspirowane rozwiązaniami zagranicznymi przyczynią się do zwiększenia konkurencyjności Polski na rynku europejskim w zakresie form prawnych prowadzenia działalności.

5. Projektodawca wyjaśnia także w uzasadnieniu projektu, dlaczego nie zastosował alternatywnego środka w postaci reformy konstrukcji jednego $\mathrm{z}$ istniejących już typów spółek kapitałowych. Otóż przeciwko takiej reformie mają przemawiać, zdaniem projektodawcy, ograniczenia prawne, zakres niezbędnych 
zmian oraz względy bezpieczeństwa obrotu. Projektodawca podnosi, że reforma spółki akcyjnej podlega ograniczeniom wynikających z dyrektywy Parlamentu Europejskiego i Rady (UE) 2017/1132 z 14 czerwca 2017 r. w sprawie niektórych aspektów prawa spółek (Dz.Urz. UE L 169 z 30 czerwca 2017 r., s. 46). Jako podstawowe ograniczenia wskazuje się $\mathrm{w}$ uzasadnieniu projektu zakaz wnoszenia wkładów na pokrycie kapitału zakładowego w postaci pracy lub usług oraz brak swobody reformy wymogów związanych z obejmowaniem akcji w zamian za aporty bez zmian przepisów na szczeblu Unii Europejskiej.

6. Projektodawca odrzucił jako rozwiązanie alternatywne wobec PSA przeprowadzenie reformy spółki z o.o., twierdząc, że wymagałoby to tak daleko idącej zmiany przepisów, że wymusiłoby zmianę zasad funkcjonowania istniejących spółek z o.o., co w praktyce doprowadziłoby do rewolucji w sposobie funkcjonowania spółki z o.o. Projektodawca twierdzi, że oznaczałoby to destabilizację obrotu wobec faktu, iż ponad $84 \%$ spółek handlowych w Polsce działa w postaci spółki z o.o., oraz prowadziłoby do nadmiernego obciążenia dla istniejących spółek.

\section{Ocena potrzeby i celu regulacji}

\section{Zasady techniki prawodawczej i zasady postępowania z kodeksami}

1. Przyjęcie każdej ustawy powinno odpowiadać zasadom techniki prawodawczej. Zasady te określa rozporządzenie Prezesa Rady Ministrów z 20 czerwca 2002 r. w sprawie „Zasad techniki prawodawczej” (t.j. Dz.U. 2016, poz. 283). Kluczowe znaczenie mają tu dyrektywy określone w $\$ 1$ ust. 1 pkt $3, \$ 1$ ust. 2 pkt 1 , 3, 4 i 6 oraz $\$ 12$ pkt 1 cytowanego wyżej rozporządzenia, stosownie do których: - podjęcie decyzji o przygotowaniu projektu ustawy poprzedza się [...]: ustaleniem możliwości podjęcia środków interwencji organów władzy publicznej, alternatywnych w stosunku do uchwalenia ustawy,

- [należy] ustalić skutki dotychczasowych uregulowań prawnych [...] $w$ danej dziedzinie,

- [należy] ustalić rozwiazania prawne alternatywne, które moga skutecznie stużyć osiagnięciu założonych celów,

- [należy] sformułować prognozy podstawowych i ubocznych skutków zamierzonych rozwiazań prawnych alternatywnych, $w$ tym wplywu tych rozwiazań na system prawa,

- [należy] dokonać wyboru optymalnego $w$ danych warunkach rozwiąania prawnego,

- uzasadnienie projektu ustawy [...] powinno zawierać [...] przedstawienie możliwości podjęcia alternatywnych w stosunku do uchwalenia projektowanej ustawy środków umożliwiających osiągnięcie zamierzonego celu, ze wskazaniem, czy środki te zostaly podjęte, a w przypadku ich podjęcia - przedstawienie osiagniętych wyników. 
Ujmując rzecz syntetyczniej, zasady techniki prawodawczej zalecają zgodnie z zasadą brzytwy Ockhama, że „Nie należy mnożyć bytów ponad potrzebę” (Entia non sunt multiplicanda praeter necessitatem).

2. Projektowane wprowadzenie do Kodeksu spółek handlowych nowego typu spółki kapitałowej stanowi zmianę o charakterze fundamentalnym i głęboko ingeruje w system polskiego prawa spółek. Wobec faktu, że zgodnie z treścią uzasadnienia projektu zmiana ta dokonuje się w drodze prostego dodania przepisów o prostej spółce akcyjnej bez całościowej reformy przepisów o spółkach kapitałowych, a więc obejmującej spółkę z o.o. i spółkę akcyjną, na potrzeby niniejszej opinii niezbędne jest syntetyczne przypomnienie stanowiska polskiego Trybunału Konstytucyjnego ${ }^{2}$ i Rady Legislacyjnej przy premierze ${ }^{3}$ oraz opinii reprezentatywnych przedstawicieli doktryny co do funkcji kodeksu jako ustawy szczególnej, która determinuje sposób reformy kodeksu.

3. W przywołanym orzeczeniu TK wyraził pogląd, stosownie do którego: [...] kodeksom przysługuje szczególne miejsce w systemie prawa ustawowego. Istotą kodeksu jest stworzenie koherentnej $i-w$ miare możliwości - zupetnej oraz trwałej regulacji $w$ danej dziedzinie prawa, kodeksy przygotowywane i uchwalane sa w odrębnej, bardziej złożonej procedurze niż „zwyczajne” ustawy, istota kodeksu jest dokonanie kodyfikacji danej gałęzi prawa. Dlatego terminy i pojęcia używane przez kodeksy traktuje się jako wzorcowe i domniemuje się, iż inne ustawy nadaja im takie samo znaczenie. Jest niesporne, że zarówno aksjologia, jak i technika tworzenia prawa traktuje kodeksy w sposób szczególny. Zasady prawidłowej legislacji wymagaja więc, by ustawodawca nader rozważnie podejmował nowelizację kodeksów [...] Jest to szczególnie ważne, gdy nowelizacja ma dotyczyć kodeksowych unormowań o charakterze zasadniczym, przesądzających sama istotę poszczególnych instytucji danej gałęzi prawa.

4. W przywołanych wyżej zaleceniach Rada Legislacyjna przy premierze RP rekomenduje, aby decyzje legislacyjne o ważnych aktach ustawodawczych podejmować po publicznym przedstawieniu ich założeń. Publiczna prezentacja takich założeń powinna następować w drodze opublikowania tzw. zielonej księgi, a nie na podstawie opublikowanego projektu. Zdaniem Rady Legislacyjnej konieczne jest: scalanie polskiego systemu prawa przez wydawanie kodeksów lub aktów o wysokim stopniu ogólności, systematycznie i w oparciu o jasne zasady regulujące obszerne dziedziny życia społecznego ${ }^{4}$.

2 Orzeczenie TK z 18 października 1994 r., sygn. akt K 2/94, OTK 1994, cz. II, poz. 36. Trybunał Konstytucyjny wydał to orzeczenie w następującym składzie: Tomasz Dybowski (przewodniczący), Lech Garlicki (sprawozdawca), Ferdynand Rymarz, Błażej Wierzbowski, Janina Zakrzewska.

3 Rada Legislacyjna przy Prezesie Rady Ministrów, Tworzenie prawa w Polsce - ocena i proponowane kierunki zmian. Raport, Listopad 2005, „Przegląd Legislacyjny” 2006, nr 1, s. 7 i nast.

4 Ibidem, s. 20. 
5. Z kolei w doktrynie podnosi się, że szczególna rola kodeksu: [p] olega [...] nie tylko na wyczerpujacym uregulowaniu obszernej dziedziny spraw, ale i na usystematyzowaniu poszczególnych dziatów prawa, ustaleniu ich przewodnich zasad, a takize stabilizacji stanu prawnego $w$ danej dziedzinie, a efekt stabilizacyjny gwarantuje m.in. zupetność, czyli objęcie kodeksem w miarę możliwości wszystkich przepisów należacych do danej dziedziny prawa ${ }^{5}$. W nauce prawa podkreśla się również, że: kodeksy sa ustawami o podstawowym znaczeniu dla danej gałęzi prawa. Przyjmuje się, że powinna cechować je stabilność i trwałośc. Stabilność kodeksu oznacza, że jego uregulowania powinny podlegać zmianom tak rzadko, jak to jest możliwe. Ingerencja ustawodawcy w przepisy kodeksu powinna być przemyślana i uzasadniona, zwłaszcza jeżeli ma być poważna [...]. Stabilności kodeksów nie sprzyja [...] sytuacja, w której modyfikacje systemu prawnego traktowane sa jako instrument o charakterze politycznym [...]. Trwałość kodeksu rozumieć [...] nale$\dot{z} y$ jako założenie, że tworzony jest on jako ustawa na długi czas, a więc również decyzja o jego zastapieniu nowa regulacja musi mieć mocne uzasadnienie i realne podstawy wynikajace $z$ potrzeb obrotu prawnego ${ }^{6}$.

6. Znaczenie kodeksu dla kształtowania jakości systemu prawnego dostrzeżono w polskim parlamencie, wprowadzając w grudniu 1995 r. szczególny porządek postępowania z projektami kodeksów, mimo że ówcześnie obowiązująca Konstytucja nie przewidywała takiego trybu․ Zwraca się uwagę, że szczególny tryb postępowania przy uchwalaniu kodeksów lub zmian do kodeksów ma: na celu zapobieżenie pochopnym decyzjom legislacyjnym oraz zapewnienie udziału specjalistów w postępowaniu, ponieważ opracowanie projektu kodeksu wymaga bardzo rozległej i głębokiej wiedzy prawniczej.

7. Podsumowując, cechą regulacji kodeksowej jest szczególny charakter kompletności regulacji. Nie chodzi tu o wyczerpujące uregulowanie wszystkich możliwych w tej sferze sytuacji zasługujących na normatywne ujęcie. Chodzi o stworzenie pewnych ogólnych zasad tej regulacji określających pewne wartości przyjęte przez ustawodawcę w kodeksie. Funkcją tych zasad jest bycie spoiwem konkretnych norm oraz rozwiązywanie występujących w systemie sprzeczności i luk. Zasadnicza funkcja kodeksu polega zatem na sformułowaniu podstawo-

5 M. Kępiński, M. Seweryński, A. Zieliński, Rola kodyfikacji na przykładzie prawa prywatnego w procesie legislacyjnym, „Przegląd Legislacyjny” 2006, nr 1, s. 95.

6 K. Weitz, Czy nowa kodyfikacja postępowania cywilnego?, „Państwo i Prawo” 2007, z. 3, s. 21.

7 Zob. S. Wronkowska, W sprawie postępowania legislacyjnego w przepisach Regulaminu Sejmu Rzeczypospolitej Polskiej, „Przegląd Sejmowy” 2000, nr 2, s. 74-83.

8 Ibidem, s. 79-80. Podobnie M. Kępiński, M. Seweryński, A. Zieliński, Rola kodyfikacji, op. cit., s. 97-98, oraz M. Kudej, Postępowania ustawodawcze w Sejmie RP, Warszawa 2002, s. 79; H. Rot, Kształtowanie systemu prawa. Więź pozioma systemu prawa, t. III, Wrocław 1984, s. 44 i nast. 
wych dla danej dziedziny prawa zasad prawa. Zasady prawa nakazują dokonywać wykładni przepisów prawa na rzecz zasady.

\section{Ocena argumentacji zawartej w uzasadnieniu projektu}

1. Fakt, że uzasadnienie projektu zawiera od strony formalnej sekcje, które tematycznie odpowiadają przedstawionym w cytowanym rozporządzeniu w sprawie „Zasad techniki prawodawczej” wymogom, nie oznacza, że wymogi tam wskazane zostały spełnione. Projektodawca wymogów „Zasad techniki prawodawczej” nie spełnił z kilku przyczyn, które zostaną wymienione poniżej.

2. Projektodawca twierdzi, że obecna regulacja spółki z o.o. i spółki akcyjnej nie spełnia potrzeb tzw. startupów. Odwoływanie się do konstrukcji spółki akcyjnej jako formy organizacyjnej nieodpowiadającej potrzebom startupu (niezależnie od wręcz błahych przykładów wskazywanych przez projektodawcę) jest obarczone intelektualnym błędem wynikającym z niedostrzeżenia przez projektodawcę, iż spółka akcyjna $z$ natury swojej jest formą organizacyjną przeznaczoną co do zasady do prowadzenia przedsięwzięć na wielką skalę. Chodzi o spółki o ugruntowanej pozycji rynkowej, które zamierzają przeprowadzić ofertę publiczną akcji na rynku regulowanym oraz spółki działające w sektorach regulowanych (np. instytucji finansowych), których model biznesowy polega na obciążaniu ryzykiem środków pozyskanych od klientów (np. banki udzielające kredytów finansowanych zgromadzonymi depozytami). W celu zilustrowania błędu podstawowego uzasadnienia projektu, który - jak się wydaje zaważył na wadliwości koncepcji wprowadzenia do Kodeksu spółek handlowych prostej spółki akcyjnej, a także nadania nowemu typowi spółki kapitałowej błędnej nazwy - warto odwołać się do wyników raportów Polskiej Agencji Rozwoju Przedsiębiorczości i Fundacji StartUp Poland. Małe i średnie przedsiębiorstwa (MŚP, ang. SMEs - Small and medium-sized enterprises) stanowią ponad 99\% z $88 \mathrm{mln}$ przedsiębiorstw w Unii i $17 \mathrm{mln}$ firm w Stanach Zjednoczonych. W Polsce sektor przedsiębiorstw jest zdominowany przez mikroprzedsiębiorstwa, których udział w strukturze wszystkich przedsiębiorstw wynosi 96\%. Co więcej, w ostatnich latach następuje wzrost liczby mikrofirm. Obecnie jest ich 1,94 $\mathrm{mln}$, o 13\% więcej niż w 2008 r. W latach 2014-2016 nastąpił ich wzrost średnio o ok. 5\% rok do roku. Mają one największy udział spośród wszystkich grup przedsiębiorstw w tworzeniu PKB (31\%), a przyjmując udział przedsiębiorstw w tworzeniu PKB jako $100 \%$, udział mikroprzedsiębiorstw zwiększa się do $41 \%$. Zatrudniają ok. 3,9 mln osób (40\% miejsc pracy). W 2016 r. przeznaczyły na inwestycje ponad 30 mld zł (16\% nakładów całego sektora przedsiębiorstw). Mikrofirmy są drugą najbardziej produktywną grupą przedsiębiorstw i najbardziej efektywną kosztowo. Z kolei małych przedsiębiorstw jest ok. 57 tys. (2,8\% polskiego sektora przedsiębiorstw). Od 2008 r. ich liczba wzrosła o 5,4\%. Mają 8\% udział w tworzeniu PKB (11\% przy założeniu, że 100\% PKB wytwarza sektor przedsiębiorstw). Zatrudniają ok. 1,2 mln zł (12,2\% miejsc pracy). Małe przedsiębiorstwa finansują inwe- 
stycje przede wszystkim środkami własnymi (60\%) oraz kredytami i pożyczkami (22\%). Charakteryzuje je najniższa przeżywalność (2/3 przeżywa rok działalności), ale w przypadku powstałych w 2011 i działających w 2015 r. wskaźnik przeżycia kolejnego roku (2016) wyniósł 99,9\%, co oznacza, że wskaźnik przeżywalności wzrasta z upływem czasu, a krytyczny jest jeden rok ${ }^{9}$.

Jeżeli chodzi o startupy jako tzw. przedsięwzięcia innowacyjne, to reprezentatywne wydają się badania Fundacji Startup Poland, które obejmują najbardziej aktywnie promowanych przez państwo małych przedsiębiorców działających w branży nowych technologii. Raport Fundacji Startup Poland z 2018 r. ${ }^{10}$ dotyczący regularności i wielkości przychodów osiąganych przez startupy, co przekłada się na ich faktyczne zdolności pozyskiwania finansowania, dowodzi, że średnio ponad 56\% startupów nie osiąga regularnych przychodów miesięcznych. Nieco ponad $25 \%$ osiąga miesięczne przychody do 100 tys. zł; ok. $11 \%$ osiąga miesięczne przychody między 100 a 500 tys. zł, a ok. 8\% powyżej 500 tys. zł. W konsekwencji 29\% startupów nie zatrudnia nikogo; 53\% od 1 do 10 osób, a $18 \%$ ponad 10 osób. Sumy pozyskanego finansowania przedstawiają się następująco: ok. 36\% startupów zebrało finansowanie do 500 tys. zł; ok. 24\% między 0,5 a $1 \mathrm{mln}$ zł; ok. $22 \%$ między 1 a $3 \mathrm{mln}$ zł; $12 \%$ między 3 a $10 \mathrm{mln}$ zł, a ok. $6 \%$ ponad $10 \mathrm{mln}$ zł. W raporcie Fundacji Startup Poland z 2018 r. czytamy, że wśród źródeł finansowania startupów zdecydowanie przeważa bootstrapping, czyli finansowanie działalności wyłącznie własnym kapitałem i kapitałem zwanym 3xF. W roku 2015 metodą bootstarpping finansowało się 60\% startupów; w roku 2016 50\%; w roku 2017 - 62\%, a w roku 2018 - 59\%.

Płyną stąd następujące wnioski. Startupy są bardzo ryzykownym celem finansowania - blisko $60 \%$ nie osiąga regularnych miesięcznych przychodów. Poziom finansowania jest bardzo niski - ok. 36\% startupów do 500 tys. zł, a 24\% do 1 mln zł, a więc znowu blisko 60\%. Około 60\% startupów nie korzysta $\mathrm{z}$ finansowania inwestorskiego i bankowego, bo są uważane za przedsiębiorstwa wysokiego ryzyka.

Wiedza na temat natury spółki akcyjnej jako formy organizacyjno-prawnej przeznaczonej do realizacji przedsięwzięć o wielkich rozmiarach ma charakter podręcznikowy i jest wykładana na IV roku studiów prawniczych, a więc czuję się zwolniony z obowiązku przeprowadzania dowodu, iż spółka akcyjna jako forma organizacyjno-prawna z założenia nie jest przeznaczona dla startupów, które wedle zaprezentowanych danych na podstawie badań Fundacji StartUp Poland należą do kategorii mikroprzedsiębiorców niezatrudniających nikogo lub mniej niż 10 osób, w większości niezdolnych do osiągania regularnych przychodów miesięcznych, $\mathrm{w}$ ok. $60 \%$ nie korzysta $\mathrm{z}$ finansowania inwestorskiego ani bankowego (bo są uważane za przedsięwzięcia wysokiego ryzyka), a te, które korzystają

9 Dane pochodzą z Raportu PARP o stanie sektora małych $i$ średnich przedsiębiorstw $w$ Polsce, Warszawa, czerwiec 2018, www.parp.gov.pl.

10 Raport Polskie STARTUPY 2018, www.startuopoland.org. 
z finansowania, zazwyczaj sięgają po finansowanie na niskim poziomie do $1 \mathrm{mln}$ zł. Już te fakty uzasadniają wniosek, że zasadnicze tezy uzasadnienia projektu są oderwane od faktów, a uzasadnienie służy „przepchnięciu projektu PSA”.

3. Wskazywane przez projektodawcę wady regulacji spółki z o.o., które mają stanowić barierę dla rozwoju startupów, są błahe, i nawet gdyby uznać je za zasadne (część rozwiązań projektu zasługuje na dyskusję, ale w ramach reformy spółki z o.o.), to są one bardzo łatwe do usunięcia w „prostej” reformie spółki z o.o. Analizując po kolei wskazywane przez projektodawcę bariery w regulacji spółki z o.o., można przedstawić następujące wnioski w kontekście cytowanych przepisów „Zasad techniki prawodawcze”:

- DOPUSZCZENIE DO WNOSZENIA DO SPÓŁKI WKŁADU W POSTACI PRACY LUB USŁUG. W pierwszej kolejności należy podnieść, że sama koncepcja wniesienia wkładu do spółki handlowej w postaci pracy lub usług nie jest nowatorska, ponieważ taka możliwość istnieje w spółkach osobowych. Od strony legislacyjnej nie ma żadnych przeszkód, aby dopuścić taki wkład w spółce z o.o. Innym zagadnieniem jest to, czy dopuszczenie takiego wkładu w warunkach polskiego systemu ochrony praw wierzycieli w spółce kapitałowej bez modyfikacji zasad odpowiedzialności wspólników odpowiada wymogowi ochrony praw wierzycieli. Ma to szczególne znaczenie w warunkach bardzo niskich wskaźników przeżywalności startupów jako mikroprzedsiębiorców. Zagrożenie dla wierzycieli z tym związane jest większe w odniesieniu do startupów, które mają być beneficjentami PSA, czego dowodzą przytoczone dane finansowe dotyczące startupów. W każdym razie taka zmiana $\mathrm{w}$ spółce $\mathrm{z}$ o.o. miałaby charakter liberalizujący, a nie nakładający nowe ciężary na wspólników,

- OgRANICZENIA UPRZYWILEJOWYWANIA UDZIAŁów - projekt PSA nie zawiera ograniczeń w uprzywilejowaniu akcji w PSA. Nie ma żadnych przeszkód natury legislacyjnej, aby znieść ograniczenia w uprzywilejowaniu udziałów w spółce z o.o. Inną kwestią jest to, czy pełna dowolność w tym zakresie nie doprowadzi do wynaturzenia natury spółki kapitałowej wyrażonej zasadą proporcjonalności głoszącą „tyle władzy w spółce ile ryzyka ekonomicznego“. W każdym razie taka zmiana w spółce z o.o. miałaby charakter liberalizujący, a nie nakładający nowe ciężary na wspólników,

- SKOMPLIKOWANY CHARAKTER INWESTYCJI W SPÓŁKĘ Z O.O. WYRAŻAJĄCY SIĘ W OBOWIĄZKU ZACHOWANIA FORMY PISEMNEJ Z PODPISAMI NOTARIALNIE POŚWIADCZONYMI PRZY ZAWIERANIU UMOWY NABYCIA UDZIAŁÓW. Nie ma żadnych przeszkód natury legislacyjnej, aby znieść wymóg zachowania formy pisemnej $\mathrm{z}$ podpisami notarialnie poświadczonymi przy zbywaniu udziałów w spółce z o.o. W każdym razie nie ma żadnych dowodów empirycznych, które w najmniejszym stopniu uzasadniałyby tezę projektodawcy, że forma zbycia udziałów w spółce z o.o. stanowi barierę dla dokonywania inwestycji w spółkę z o.o. Jest wręcz przeciwnie. Popularność spółki z o.o., na którą zwraca uwagę sam projektodawca, dowodzi, że jest to co najwyżej drobna niedogodność, która łatwo może być usu- 
nięta w ramach reformy spółki z o.o. W każdym razie taka zmiana w spółce z o.o. miałaby charakter liberalizujący, a nie nakładający nowe ciężary na wspólników, - BRAK INKORPOROWANIA UDZIAŁÓW W SPÓŁCE Z O.O. W DOKUMENCIE I W ZAPISIE ELEKTRONICZNYM, CZYLI BRAK PRZYZNANIA UDZIAEOM STATUSU PAPIERU WARTOŚCIOWEGo. Nie ma żadnych przeszkód legislacyjnych, aby udział w spółce z o.o. nazwać akcją i nadać mu status papieru wartościowego z zastrzeżeniem, że nie może on być przedmiotem oferty publicznej ani obrotu na rynku zorganizowanym. Historycznie udział w spółce z o.o. jest w istocie bezdokumentową akcją pozbawioną statusu papieru wartościowego. Taki status udziału w spółce z o.o. był podyktowany właśnie dążeniem do zakazu obrotu udziałami na rynku publicznym. Na marginesie, projektodawca nie dostrzegł, że udział z natury jest zdematerializowany. W każdym razie taka zmiana w spółce $\mathrm{z}$ o.o. miałaby charakter liberalizujący, a nie nakładający nowe ciężary na wspólników,

- BRAK MOŻliwości TWORZENia UdZIAŁóW NIEMYCH W SPÓ£CE Z O.o. Nie ma żadnych przeszkód legislacyjnych, aby zezwolić na tworzenie w spółce z o.o. udziałów niemych. W każdym razie taka zmiana w spółce z o.o. miałaby charakter liberalizujący, a nie nakładający nowe ciężary na wspólników,

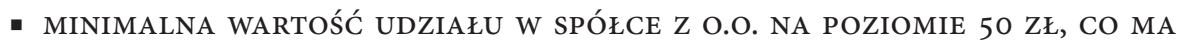
OGRANICZAĆ MOŻLIWOŚCI KORZYSTANIA Z ROSNĄCEGO ZNACZENIA POZYSKIWANIA KAPITAŁU W DRODZE TZW. CROWDFUNDINGU (FINANSOWANIE SPOŁECZNOŚCIOWE). Pomijając fakt, że argument, iż wartość nominalna udziału na poziomie 50 zł ogranicza możliwość korzystania z tzw. crowdfundingu, jest dość zaskakujący, biorąc pod uwagę siłę nabywczą 50 zł, i w konsekwencji zupełnie nieprzekonujący, nie ma żadnych przeszkód, aby ustalić minimalną wartość udziałów w spółce z o.o. na poziomie 1 grosza tak jak w spółce akcyjnej. W każdym razie taka zmiana w spółce z o.o. miałaby charakter liberalizujący, a nie nakładający nowe ciężary na wspólników.

Przeprowadzony test na potrzebę wprowadzenia PSA wedle analizy zasadniczych barier dla startupów podniesionych w uzasadnieniu projektu dowodzi, że zmiany wskazywane przez projektodawcę można wprowadzić w wyniku nieskomplikowanej reformy spółki z o.o. Projektodawca nie podjął rzeczywistej próby uprawdopodobnienia, czy deklarowane cele można osiągnąć w wyniku reformy spółki z o.o., a jedynie ograniczył się do arbitralnego stwierdzenia w tym zakresie.

3. Niejako na marginesie wymaga zwrócenia uwagi, że całe uzasadnienie odwołuje się do konieczności stworzenia w istocie specjalistycznej formy organizacyjno-prawnej dla specyficznego przedsięwzięcia gospodarczego, jakim ma być startup. Pomijając fakt, że projektodawca nie udowodnił, dlaczego startupy z branży nowych technologii wymagają szczególnej formy organizacyjno-prawnej (która - jak projektodawca sam przyznaje - ostatecznie może być wykorzystana przez każdą spółkę), to nawet gdyby hipotetyczne uznać taką potrzebę, 
prowadziłoby to do wniosku, iż właściwym narzędziem legislacyjnym byłoby uchwalenie tzw. specustawy dla startupów, a nie rozbijanie systemu prawa spółek ujętego w Kodeksie spółek handlowych. Jest to typowa metoda stosowana w prawie prywatnym, w tym w prawie spółek, które dostrzega zjawisko spółek specjalistycznych (np. instytucje finansowe, spółki wodne, spółdzielnie).

4. Całkowicie niezrozumiały jest wniosek projektodawcy, według którego wprowadzenie postulowanych zmian (kluczowych) w ramach spółki z o.o. prowadziłoby do destabilizacji obrotu oraz nadmiernego obciążenia dla tych spółek. Jak już wykazano w niniejszej opinii i jak przekonuje sam projektodawca, celem zmian jest uelastycznienie i zliberalizowanie działalności gospodarczej w postaci spółki kapitałowej. Prowadzi to do logicznego wniosku, że wspólnicy spółek z o.o. skorzystaliby na proponowanych zmianach, które - jeżeli przyjąć optykę projektodawcy - mają luzować nadmiernie sztywny gorset prawny regulacji spółki z o.o. i spółki akcyjnej.

5. Twierdzenie projektodawcy o braku możliwości przeprowadzenia reformy spółki z o.o. jako alternatywy wobec PSA brzmi niewiarygodnie także, jeśli weźmie się pod uwagę czas i historię konsultacji projektu PSA. Prace nad PSA rozpoczęły się latem 2016 r., a więc trwają już blisko 3 lata. Jest to wystarczająco długi okres na sprostanie zaleceniom Rady Legislacyjnej przy premierze przedstawienia proponowanych zmian w postaci zielonej księgi i na podstawie konsultacji dokonanie reformy w istniejącym systemie prawa spółek. O braku woli dyskutowania o rozwiązaniu alternatywnym wobec PSA dowodzi fakt, że wobec bierności Ministerstwa Przedsiębiorczości i Technologii Katedra Prawa Handlowego Wydziału Prawa i Administracji Uniwersytetu Warszawskiego wspólnie z Zakładem Prawa Gospodarczego Szkoły Głównej Handlowej zorganizowała konferencję poświęconą projektowi prostej spółki akcyjnej, na którą zaproszono pomysłodawcę, czyli Ministerstwo Przedsiębiorczości i Technologii (MPiT) oraz twórców projektu działających w zespole przy MPiT. MPiT i twórcy projektu odmówili prezentacji projektu na konferencji. Poprzednik MPiT, Ministerstwo Rozwoju, co prawda zorganizował 29 listopada 2017 r. konferencję pt. „Prosta Spółka Akcyjna - nowa spółka dla innowacyjnego biznesu”, ale na zapoznanie się z projektem środowisko naukowe otrzymało 1,5 tygodnia (sic!), a o recenzję projektu poproszono aż... dwóch autorów. Konsultacje zmian w kodeksie, które zaleca Rada Legislacyjna przy premierze RP, mają mieć charakter realny, a nie służyć tylko wykazaniu od strony formalnej, że odbyły się.

6. Wymaga także podkreślenia, że na konieczność prowadzenia dalszych prac z udziałem środowiska naukowego nad projektem wskazała Rada Legislacyjna przy premierze, oceniając projekt PSA bardzo negatywnie w opinii przyjętej na posiedzeniu 22 czerwca 2018 r. Konkluzja Rady Legislacyjnej była następująca: projekt nowelizacji k.s.h. [...] wprowadzający prosta spółkę akcyjna rodzi tak duża ilość wątpliwości i zastrzeżeń, iż w tym kształcie winien zostać skierowany do dalszych prac analitycznych przy udziale środowiska naukowego. Wprowadzenie tego 
projektu może bowiem godzić w bezpieczeństwo obrotu prawnego przez faktyczne wprowadzenie do prawa polskiego zamiast prostej spótki akcyjnej tzw. „spółki akcyjnej bis” czy „spótki akcyjnej light”. Projektowana regulacja nie uwzględnia przepisów dotyczacych pozostałych spótek kapitałowych, co przejawia się m.in. $w$ tworzeniu własnej siatki pojęciowej. Wywoła to z kolei fundamentalne trudności interpretacyjne na gruncie istniejących regulacji [...]. Tym samym przedłożony do zaopiniowania projekt $w$ istocie swej nie spetni zasadniczego celu, jaki został sformułowany w uzasadnieniu, a polegający a ukształtowaniu „nowoczesnej spótki niepublicznej dla nowoczesnej gospodarki”, a w szczególności spótki przeznaczonej do realizacji nowych przedsięwzięć podejmowanych $w$ warunkach dużej niepewności rynkowej, czyli tzw. startupów.

\section{Najważniejsze uwagi szczegółowe}

\section{Autonomia woli kształtowania umowy PSA i natura PSA}

1. W uzasadnieniu oraz w „promocji” PSA przez MPiT podkreśla się, że jej szczególną cechą oczekiwaną przez startupy jest swoboda kształtowania przez akcjonariuszy PSA postanowień umowy spółki PSA (s. 13-14 uzasadnienia projektu). W projekcie nie ma jednak przepisu, który sankcjonowałby taką szczególną cechę PSA w opozycji do swobody w kształtowaniu postanowień umowy spółki z o.o. Zasadę swobody umów w odniesieniu do kształtowania postanowień umowy PSA projektodawca wywodzi z art. 2 k.s.h. w związku z art. $353^{1}$ Kodeksu cywilnego. Przepis art. 2 k.s.h. stanowi, że w sprawach nieuregulowanych w Kodeksie spółek handlowych stosuje się przepisy Kodeksu cywilnego z zastrzeżeniem, że jeżeli wymaga tego właściwość (natura) stosunku prawnego spółki handlowej, przepisy Kodeksu cywilnego stosuje się odpowiednio. Projektodawca nie dodaje jednak, że zasada swobody umów obligacyjnych wyrażona w art. $353^{1}$ Kodeksu cywilnego stanowi punkt wyjścia do badania zakresu jej zastosowania w odniesieniu do swobody kształtowania umowy każdej spółki handlowej, w tym do swobody kształtowania statutu spółki akcyjnej w kontekście wyjątków od zasady surowości statutu spółki akcyjnej (art. $304 \$ 3$ i 4 k.s.h.). Rozwiązanie to nie jest zatem specyficzne dla prostej spółki akcyjnej.

2. Z uzasadnienia projektu (s. 10) wynika, że istota (natura) prostej spółki akcyjnej, która ma wyróżniać ją od spółki z o.o. i spółki akcyjnej, polega na tym, że prosta spółka akcyjna jest spółką kapitałową zawiązaną w każdym celu prawnie dopuszczalnym przez jedną albo kilka osób, które nie odpowiadają za zobowiązania spółki i które są zobowiązane do wniesienia na pokrycie obejmowanych akcji wkładów pieniężnych lub wkładów niepieniężnych. Celem zidentyfikowania natury oznaczonego stosunku prawnego czy instytucji prawnej jest wyodrębnienie jej cech konstytutywnych, czyli pozwalających na wyróżnienie jej jako podzbioru w ramach większego zbioru (tu: zbioru spółek kapitałowych). Ma to 
wpływ na interpretację wszystkich przepisów o prostej spółce akcyjnej, określenie ich relacji do przepisów o spółce z o.o. i spółce akcyjnej, a przede wszystkim na faktyczne znaczenie proklamowanej w uzasadnieniu projektu oraz w wypowiedziach i publikacjach promujących PSA swobody jej akcjonariuszy w kształtowaniu postanowień umowy prostej spółki akcyjnej (ograniczonej naturą prostej spółki akcyjnej i przepisami bezwzględnie wiążącymi, które w szczególności służą ochronie prawa akcjonariuszy mniejszościowych).

Przyznaje to sam projektodawca (s. 41 i 42 uzasadnienia) przy omawianiu przywilejów akcyjnych i uprawnieniu indywidualnych akcjonariuszy, wskazując, że akcjonariusze PSA mają swobodę w określeniu sposobu i zakresu uprzywilejowania akcji oraz uprawnień indywidualnych akcjonariuszy. Projektodawca zwraca uwagę, że jest to rozwiązanie odmienne w porównaniu ze spółką z o.o. i spółką akcyjną, gdzie ustawodawca wprowadził ustawowe ograniczenia w uprzywilejowaniu akcji i w zakresie uprawnień osobistych akcjonariuszy (zob. art. $174 \$ 4$, art. 196, art. 352, art. 353 k.s.h.). Skoro jednak wprowadza się fundamentalnie odmienne rozwiązanie w zakresie swobody kształtowania uprawnień akcjonariuszy w prostej spółce akcyjnej w porównaniu z rozwiązaniem obowiązującym w spółce z o.o. i spółce akcyjnej przy jednoczesnym wskazaniu, że zasadą obowiązującą w prostej spółce akcyjnej jest zasada jedna akcja - jeden głos, tak jak w spółce z o.o. i spółce akcyjnej, to rzeczywiście z natury prostej spółki akcyjnej powinno jasno wynikać, że odmiennie niż w spółce z o.o. na jedną akcję może przypadać np. 25 głosów, podczas gdy na jeden udział w spółce z o.o. może przypadać nie więcej niż trzy głosy, a na jedną akcję w spółce akcyjnej może przypadać nie więcej niż dwa głosy.

3. W związku z przyjętą $\mathrm{w}$ projekcie konstrukcją PSA zadaniem sądownictwa i doktryny będzie ustalenie, czy oraz w jakim zakresie treść i zakres uprzywilejowania akcji oraz osobistego uprzywilejowania akcjonariusza w prostej spółce akcyjnej będzie mógł odbiegać od standardów ustanowionych w spółce z o.o. i spółce akcyjnej. Orzecznictwo i doktryna będą poszukiwać kryteriów dla rozstrzygnięcia, jak dalece można uprzywilejować akcjonariusza w prostej spółce akcyjnej, a więc np. czy dopuszczalne będzie przyznanie jednej akcji 5 głosów, 10, 15, a może 100 głosów; czy dopuszczalne będzie doprowadzenie do sytuacji, w której dojdzie do zerwania związku między ponoszonym ryzykiem ekonomicznym akcjonariusza w prostej spółce akcyjnej a jego wpływem na decydowanie o sprawach spółki (tzw. złota akcja); czy dopuszczalne będzie ukształtowanie struktury głosów bądź udziału w zysku na walnym zgromadzeniu akcjonariuszy (WZA) prostej spółki akcyjnej tak, aby akcjonariusz mający mniejszość w udziale w zysku spółki (np. 10\%) miał większość w ogólnej liczbie głosów na WZA prostej spółki akcyjnej (np. 80\%) albo czy akcjonariusz mający większość w udziale w zysku spółki (np. 90\%) miał mniejszość w ogólnej liczbie głosów na WZA prostej spółki akcyjnej (np. 5\%) itd.

4. Należy spodziewać się, że orzecznictwo i doktryna będą brały pod uwagę następujące kryteria: 
- BRAK CECH WYRÓŻNIAJĄCYCH NATURĘ PSA OD SPÓ£KI Z O.O. I SPÓ£KI AKCYJNEJ - zdefiniowana przez projektodawcę natura prostej spółki akcyjnej nie wyróżnia jej ani od spółki z o.o., ani od spółki akcyjnej. Skoro bowiem cechą konstytutywną prostej spółki akcyjnej jest osobowość prawna, możliwość zawiązania jej w każdym celu prawnie dozwolonym oraz obowiązek wniesienia wkładów do spółki, to są to cechy analogiczne z cechami konstytutywnymi spółki z o.o. i spółki akcyjnej,

- HYBRydowość PSA JAKo SUMA (NIEKONSEKWENTNA) PRZEPISÓW O SPÓŁCE Z O.O. I SPÓŁCE AKCYJNEJ WYMAGAJĄCA USTALENIA, CZY NATURA PSA CIĄŻY BARDZIEJ W KIERUNKU SPÓŁKI Z O.O., CZY SPÓŁKI AKCYJNEJ - liczne rozwiązania w projekcie PSA wzorowane na regulacji spółki z o.o. i spółki akcyjnej (w istocie regulacja PSA jest zlepkiem przepisów o spółce z o.o., spółce akcyjnej oraz spółki europejskiej), a także odesłania do przepisów o spółce akcyjnej, stworzą poważne trudności w ustaleniu, czy regulacja PSA bardziej ciąży w kierunku regulacji spółki z o.o., czy bardziej w kierunku regulacji spółki akcyjnej,

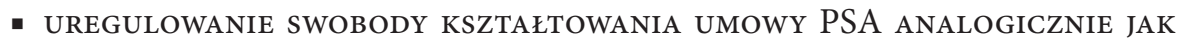
W SPÓŁCE Z O.O. - w regulacji PSA ostatecznie zrezygnowano z przepisu, który na wzór art. $353^{1}$ k.c. ustanawiałby zasadę swobody umów przy kształtowaniu treści umowy prostej spółki akcyjnej. Wynika stąd, że owa „reklamowana“ swoboda przy kształtowaniu treści umowy prostej spółki akcyjnej, większa niż przy spółce z o.o. i spółce akcyjnej, jest w istocie kopią swobody przy kształtowaniu treści umowy spółki z o.o. Projekt regulacji o PSA - w ślad za regulacją o spółce z o.o. - nie zawiera bowiem zasady surowości statutu spółki akcyjnej wyrażonej w art. $304 \$ 3$ i 4 k.s.h.,

- UtRZyMANiE w PSA ZASAdy JEDNA AKCJA - JEDEN GŁos - w odniesieniu do PSA utrzymano zasadę jedna akcja - jeden głos (art. 30023 projektu), zgodnie z którą akcja daje prawo do jednego głosu. Oznacza to, że w odniesieniu do swobody uprzywilejowania akcji w prostej spółce akcyjnej będzie miała zastosowanie zasada exceptiones non sunt extendendae (wyjątków nie należy interpretować rozszerzająco),

- ZASTOSOWANIE W PSA TERMinOlOgiI JAK W SPÓŁCE AKCYjNEj - szczególny związek prostej spółki akcyjnej ze spółką akcyjną można wywodzić z nazwy PSA odwołującej się do spółki akcyjnej; nazwy udziałowców prostej spółki akcyjnej jako akcjonariuszy; wprowadzenia rozbudowanego modelu zarządzania i nadzoru w PSA charakterystycznego dla rozwiązań przyjmowanych w spółkach akcyjnych publicznych, spółce europejskiej i spółkach akcyjnych regulowanych (np. banki, ubezpieczyciele, towarzystwa funduszy inwestycyjnych, powszechne towarzystwa emerytalne),

- UZASADNienie PROJEKTODAWCy o SZCZEgólnym ZWiąZKu PSA ZE sPóŁKĄ AKCYJNĄ - w uzasadnieniu projektu zostało zawarte wyjaśnienie (s. 8), że prostą spółkę akcyjną: ze spółkami kapitałowymi, a zwłaszcza spółką akcyjna, łączy [...] rozbudowany mechanizm pozyskiwania kapitału $w$ drodze emisji akcji. 
5. Z faktu, że swoboda kształtowania umowy PSA została uregulowana analogicznie jak w spółce $\mathrm{z}$ o.o. wynika, iż nieprawdą jest jakoby projekt PSA wprowadzał kontraktowy model spółki kapitałowej oparty na zasadzie swobody umów tak jak w przypadku umowy obligacyjnej. Z natury rzeczy zasada swobody umów w prawie spółek nigdy nie będzie oparta na wzorcu kompetencji generalnej. Jest to model wzorca kompetencji szczególnej, a więc zakładającej numerus clausus typów spółek, a nie katalog otwarty umów ${ }^{11}$. Niezależnie od tego, jak dalece będzie testowana zasada swobody umów w odniesieniu do prawa spółek handlowych, w tym do PSA, tak długo jak w prawie spółek będzie obowiązywać zamknięty katalogu typów spółek, zasada swobody umów w prawie spółek handlowych będzie oparta na wzorcu kompetencji szczególnej, który był dyskutowany w pracach nad Kodeksem zobowiązań, ale trafnie nie przyjął się wobec umów obligacyjnych. Wzorzec ten zakłada przecież, że swoboda kontraktowania ogranicza się do wyboru spośród wyróżnionego w ustawie katalogu umów i kształtowania ich treści w granicach ustanowionych ustawą przepisów dyspozytywnych mocno ograniczanych ich naturą, słusznością (ze względu na korzystanie z modelu spółki jako wehikułu do pozyskiwania kapitału na zewnątrz) oraz względami bezpieczeństwa obrotu ze względu na stopień ingerencji spółki w interesy jej wierzycieli oraz wpływ konfliktów wspólników w spółce nie tylko na ich stosunki wewnętrzne, ale także na stosunki zewnętrzne, a więc na bezpieczeństwo wierzycieli spółki, czyli stabilności i bezpieczeństwo obrotu. Środowisko, w jakim funkcjonuje zasada swobody umów w prawie spółek handlowych, jest znacznie bardziej złożone niż w przypadku umów obligacyjnych. Skoro PSA jest wskazywana przez projektodawcę jako wehikuł do pozyskiwania kapitału, to prowadzi to do wniosku, że jej natura jako granica swobody kształtowania np. praw akcjonariuszy w kontekście przyznawanych im przywilejów będzie ciążyć w kierunku ograniczeń uznanych jako standard w spółce akcyjnej.

6. Podsumowując, moje ponad 25-letnie doświadczenie akademika i praktyka, a także ponad 12-letnie doświadczenie legislacyjne, w tym przez 10 lat jako członka Komisji Kodyfikacyjnej Prawa Cywilnego upoważnia mnie do sformułowania poglądu (prognozy), iż orzecznictwo i doktryna będą przez wiele lat debatowały nad naturą PSA w odniesieniu do natury spółki z o.o. i spółki akcyjnej oraz że należy liczyć się z wysokim ryzykiem uznania, iż za standard odejścia od zasady jedna akcja - jeden głos zostanie przyjęty standard obowiązujący w spółce akcyjnej jako spółce, do której prosta spółka akcyjna ciąży najbardziej. Innymi słowy, prowadzi to do wniosku, że niezależnie od deklaracji projektodawcy, odpowiedzialny doradca prawny będzie musiał uprzedzić klientów, iż istnieje wysokie ryzyko, że przywileje przyznawane akcjonariuszom w PSA odbiegające lub znacznie odbiegające od przywilejów dopuszczalnych w spółce akcyjnej zostaną

11 Zob. M. Romanowski [w:] System prawa prywatnego, t. XVI, Prawo spółek osobowych, red. A. Szajkowski, Warszawa 2016, s. 210, 218-220. 
uznane przez sądy za sprzeczne z naturą spółki kapitałowej, w tym PSA, a więc nieważne.

Metoda wolności kształtowania umowy PSA została oparta na modelu analogicznym do spółki z o.o., a więc przez wyraźne wskazywanie w konkretnych przepisach, że umowa spółki PSA może zawierać rozwiązania odmienne, ale w granicach określonych naturą spółki, zasadami współżycia społecznego i przepisami prawa. W modelu wzorca kompetencji szczególnej jako wyznacznika treści swobody kształtowania umów strony w praktyce w znacznie większym stopniu ograniczone są szczegółowymi przepisami dyspozytywnymi, które stanowią naturalny (w modelu numerus clausus umów spółek handlowych) punkt odniesienia dla wypełniania treścią zasad współżycia społecznego i natury umowy jako stosunku prawnego. Owa większa swoboda przy kształtowaniu umowy spółki PSA może okazać się zatem iluzoryczna, a z pewnością jest obarczona dużym ryzykiem niepewności. Co do rzeczywistego zakresu swobody kształtowania umowy PSA pewna jest... niepewność.

\section{Tryb powstania PSA}

Tryb powstania PSA (art. $300^{14}$ projektu) jest co do zasady wzorowany na przepisach o spółce $\mathrm{z}$ o.o. Zasadnicza różnica ma polegać na zwolnieniu z obowiązku wniesienia wkładu przed rejestracją spółki na pokrycie obejmowanych akcji. Termin ten określa umowa spółki, uchwała akcjonariuszy lub umowa PSA. Rozwiązanie takie wobec niskiej już obecnie wysokości minimalnego wkładu na pokrycie kapitału zakładowego do spółki z o.o. (5 tys. zł) nie stanowi jednak istotnej przewagi konkurencyjnej PSA, a w każdym razie nie uzasadnia tworzenia odrębnego typu spółki kapitałowej. Nie ma także przeszkód, aby o takim rozwiązaniu dyskutować w odniesieniu do spółki z o.o., tym bardziej że w istocie jest ono wzorowane na rozwiązaniu obowiązującym w spółce akcyjnej (art. $309 \$ 3$ i 4 k.s.h.), który m.in. w odniesieniu do wkładów pieniężnych nakazuje wpłatę przed rejestracją kapitału zakładowego w wysokości jego jednej czwartej wartości nominalnej (notabene oznacza to, że do założenia nawet spółki akcyjnej wymagane jest obecnie uiszczenie wkładu w wysokości 25 tys. zł). Odpowiedzialność za wniesienie wkładu została uregulowana tak jak w spółce z o.o. (art. 300 ${ }^{122}$ i $300^{123}$ projektu). Wynika stąd, że elastyczność zakładania PSA, w tym wykorzystanie drogi online, jest wzorowana na rozwiązaniach obowiązujących od wielu lat w odniesieniu do spółki z o.o. (niska wysokość kapitału zakładowego - 5 tys. zł i system rejestracji online - tzw. system S24). Nie uzasadnia to tworzenia nowej konstrukcji prawnej.

\section{Forma umowy PSA}

Forma umowy PSA jest co do zasady wzorowana na przepisach o spółce z o.o. Należy zwrócić uwagę, że projekt wyklucza możliwość założenia PSA w trybie S24 (online), jeżeli przedmiotem wkładu mają być wkłady niepieniężne, w tym 
w postaci pracy i usług, a także gdy akcjonariusze będą chcieli zawrzeć w umowie spółki postanowienia niewystępujące we wzorcu umowy spółki zakładanej w systemie S24. Oznacza to, że wbrew twierdzeniom projektodawcy założenie PSA nie będzie ani szybsze, ani prostsze, ani bardziej elastyczne, ani tańsze od założenia spółki z o.o.

\section{PSA w organizacji i rejestracja PSA}

W zakresie regulacji PSA w organizacji i rejestracji PSA rozwiązania w projekcie kopiują rozwiązania przyjęte w odniesieniu do spółki z o.o. i spółki akcyjnej. Projektodawca część tych rozwiązań powtarza, a w części stosuje technikę odesłania do przepisów o spółce z o.o. (zob. np. odesłanie do art. $164 \$ 3$, art. 165, art. 169, art. 170 i art. 172 k.s.h.). Jest to sprzeczne z zasadą tworzenia kodeksu, którego celem jest unikanie powtarzania norm prawnych w obrębie jednego aktu.

\section{Struktura majątkowa PSA}

1. Zasadnicza zmiana, która rzeczywiście różni PSA od spółki z o.o. i spółki akcyjnej, polega na wprowadzeniu modelu akcji bez wartości nominalnej i odejście od instytucji kapitału zakładowego. Ze względu na ograniczone rozmiary niniejszej opinii nie sposób ustosunkować się do tej zmiany w sposób szczegółowy. Wystarczy jednak wskazać, że wprowadzenie takiej zmiany było już testowane przy okazji reformy struktury majątkowej spółki z o.o. i spotkało się ze zdecydowaną krytyką miażdżącej większości polskiej doktryny prawa spółek ${ }^{12}$. Inną kwestią jest ocena podnoszonych argumentów.

2. Zasadniczym przedmiotem dyskusji w doktrynie nie jest ochrona instytucji kapitału zakładowego dla „samej” obrony tej instytucji, ale poszukiwanie sposobu efektywnej ochrony wierzycieli przy eliminacji negatywnych efektów ubocznych instytucji kapitału zakładowego ograniczających swobodę restrukturyzacji spółki i dokonywania wypłat ze spółki mimo braku zagrożenia interesów wierzycieli (przeciwdziałanie zjawisku nieuzasadnionego „uwięzienia” kapitału w spółce kapitałowej). Obecnie spór nie toczy się zatem o to, czy minimalna wysokość kapitału zakładowego chroni wierzycieli (w spółkach zamkniętych o niewielkim kapitale zakładowym jest oczywiste, że nie chroni), ale czy należy i w jaki sposób wprowadzać mechanizmy odpowiedzialności za niedokapitalizowanie spółki, niedostosowanie w umowie spółki wysokości kapitału udziałowego (zakładowego, akcyjnego) do rozmiarów działalności spółki, odpowiedzialności tak zwanych rzeczywistych zarządzających (de facto i shadow directors) itd.

3. Wprowadzenie do PSA udziałów beznominałowych (bez wartości nominalnej) nie tylko nie prowadzi do uproszczenia regulacji prawa spółek, ale do jej dodatkowego skomplikowania w związku z doprowadzeniem w systemie pol-

12 Zob. np. przegląd stanowisk zebranych w „Przeglądzie Prawa Handlowego” 2011, nr 9. 
skiego prawa spółek kapitałowych do współistnienia udziałów (akcji) nominałowych i beznominałowych w zależności od typu spółki. Jest to tym bardziej zabieg chybiony w odniesieniu do startupów, ponieważ w założeniu startup w postaci PSA docelowo ma zostać spółką publiczną. Jest to koncepcja chybiona także ze względu na dopuszczalność przekształcania spółek kapitałowych w zależności od potrzeb w inny typ spółki kapitałowej, np. PSA w spółkę akcyjną, PSA w spółkę z o.o., spółka z o.o. w PSA, spółka akcyjna w PSA. W zakresie tak kluczowym jak organizacja prawna struktury majątkowej spółki przyjęcie jednolitych konstrukcji i terminów jest szczególnie ważne dla uniknięcia komplikacji i kosztów związanych z koniecznością adaptacji różnych rozwiązań z różnych typów spółek kapitałowych w procesach przekształceń lub restrukturyzacji.

4. Ekonomiczna analiza prawa nakazuje dokonać oceny kosztów wprowadzania nowej instytucji prawnej mierzonej nie tylko wysiłkiem ustawodawcy, ale także, a nawet przede wszystkim, uczestników obrotu, którym koncepcja udziałów nominałowych i kapitału zakładowego jest dobrze znana. Stopień złożoności problemu ilustruje będący przedmiotem debaty w Polsce projekt reformy struktury majątkowej spółki z o.o., który zakładał możliwość istnienia spółek z o.o. z udziałami nominałowymi (z kapitałem zakładowym), spółki z o.o. z udziałami beznominałowymi (z kapitałem udziałowym) oraz spółki z o.o. z udziałami nominałowymi i beznominałowymi, a więc $z$ kapitałem zakładowym i udziałowym. Celem regulacji jest nie tylko jej poprawność teoretyczna, ale przede wszystkim użyteczność praktyczna. Podkreślić przy tym należy, że konstrukcja wartości nominalnej udziałów wcale nie musi stanowić przeszkody w razie konieczności szybkiej restrukturyzacji spółki w związku z koniecznością zwoływania postępowania konwokacyjnego wierzycieli. Obowiązek zwoływania postępowania konwokacyjnego jako instrumentu ochrony wierzycieli można bowiem zastąpić mechanizmem bardziej efektywnym, jakim jest test wypłacalności. Projektodawcy całkowicie pominęli poszukiwania rozwiązań alternatywnych o znacznie mniejszym stopniu ingerencji w rozwiązania istniejące. Cel w postaci ułatwienia restrukturyzacji struktury kapitałów spółki można osiągnąć znacznie mniej radykalnymi niż proponowana w przeszłości i obecnie kopiowana metoda. Koszty wprowadzenia udziałów beznominałowych przewyższają korzyści stąd płynące. Wprowadzanie udziałów beznominałowych stoi w sprzeczności z celem, jakim jest upraszczanie regulacji spółki kapitałowej adresowanej do mikro, małych i średnich przedsiębiorców.

5. O tym, że można poszukiwać uzdrowienia funkcjonalności kapitału zakładowego bez demontażu dotychczasowych konstrukcji dowodzą zmiany liberalizujące instytucję kapitału zakładowego, na które zdecydował się holenderski ustawodawca w spółce Besloten Vennootschap. Reforma holenderskiego prawa spółek kapitałowych z 2012 r. zniosła próg minimalnego kapitału zakładowego, wyeliminowała zakaz financial assistance, zlikwidowała większość ograniczeń dotyczących nabycia akcji własnych oraz zniosła ograniczenia proceduralne w zakresie obniżania kapitału zakładowego, odeszła od powszechnie, choć z małymi 
modyfikacjami, w państwach UE przyjętej zasady, że wypłaty na rzecz wspólników mogą być dokonywane tylko z aktywów netto przewyższających kwotę kapitału zakładowego. Zreformowana regulacja holenderskiej sp. z o.o. nie przewiduje, żeby kapitał zakładowy wyznaczał pulę środków „uwięzionych” w spółce. Wypłata na rzecz wspólników jest możliwa wówczas, gdy będzie zasługiwała na pozytywną ocenę pod kątem dwóch obligatoryjnych testów, które zobowiązany jest dokonać zarząd. Po pierwsze, do wypłaty może dojść tylko wtedy, gdy po jej dokonaniu w spółce pozostaną aktywa netto przewyższające kwotę ustawowych rezerw (test wypłacalności). Po drugie, nie może dojść do wypłaty, gdy zarząd jest świadom lub powinien rozsądnie przewidywać, że jej dokonanie spowodowałoby brak możliwości spłacania wymagalnych zobowiązań spółki (test płynności). Pulę środków „uwięzionych” stanowią więc obecnie jedynie ustawowe rezerwy, natomiast na zarządzie spoczywa obowiązek oceny płynności spółki. Instytucją naturalnie ograniczającą arbitralność zarządu w „wykonywaniu testów” jest odpowiedzialność członków zarządu wobec spółki, w przypadku gdy po dokonaniu dystrybucji spółka nie będzie w stanie zaspokajać swoich zobowiązań. Członkowie zarządu są odpowiedzialni indywidualnie i solidarnie za dokonanie dystrybucji niezgodnej z testem wypłacalności i płynności, co oznacza, że są zobowiązani do zwrotu spółce kwoty dokonanej wypłaty. Reżim ten nie tylko dotyka członków zarządu - ustawodawca holenderski zdecydował się na konstrukcję zbliżoną do tzw. przebicia zasłony korporacyjnej, obejmując odpowiedzialnością również wspólników i menedżerów spółki, którzy nie piastując funkcji członka zarządu, mają faktyczny wpływ na zarządzanie spółką, pod warunkiem że mieli świadomość lub mogli rozsądnie przypuszczać, że wypłata na rzecz wspólników z majątku spółki doprowadzi do niemożności zaspokajania wymagalnych zobowiązań przez spółkę. Opisuję to jako przykład ilustrujący, że stosownie do uwarunkowań krajowego systemu prawa spółek, systemu ochrony wierzycieli, a także rozwoju praktyki obrotu można poszukiwać środków alternatywnych $\mathrm{w}$ istniejącym już systemie, a nie twierdzić, że jedyną drogą jest jego demontaż, w tym wprowadzanie nowego typu spółki kapitałowej o dość „mglistej” naturze.

\section{Wkład w postaci świadczenia pracy i usług}

1. Jak już zauważono, uregulowanie dopuszczalności wnoszenia wkładu w postaci świadczenia pracy i usług może być dokonane w spółce z o.o. Wprowadzenie takiej możliwości wymaga jednak wszechstronnej analizy z punktu widzenia konieczności dokonania korekt w zasadzie wyłączonej odpowiedzialności wspólników za zobowiązania spółki oraz szerzej stopnia ochrony wierzycieli spółek. Analiza taka nie została dokonana przez projektodawcę.

2. Wkłady w postaci świadczenia pracy i usług w spółce kapitałowej są dopuszczalne w nielicznych ustawodawstwach europejskich a kluczowym przykładem jest wskazywana wcześniej Francja. Jednak we Francji dopuszczenie wkładu w postaci pracy i usług nastąpiło najpierw w SARL (odpowiednik polskiej 
spółki z o.o.), a dopiero później w SAS (uproszczona spółka akcyjna). Pomijając szczegółową analizę funkcjonowania tej konstrukcji w prawie francuskim (której projektodawca nie dokonał), na potrzeby niniejszej opinii wystarczy ograniczyć się do stwierdzenia, że funkcjonuje ona w reżimie większej odpowiedzialności wspólników za zobowiązania spółki kapitałowej.

3. Analiza projektu i jego uzasadnienia jest przy tym dość zaskakująca, jeśli weźmiemy pod uwagę publiczne przekazy promotorów projektu. Wkład w postaci pracy lub usług dopuszczalny w projekcie nie ma zdolności aportowej, a więc nie może być zaliczony do kapitału akcyjnego, czyli nie tworzy wartości pokrywającej kapitał akcyjny. Projektodawca trafnie zwraca uwagę, że: $W$ przepisach o rachunkowości, zarówno wynikających z polskiej ustawy o rachunkowości jak i z międzynarodowych standardów rachunkowości, podstawowym problemem przy ocenie możliwości ujęcia w bilansie takiego aportu jest problem dopuszczalności ujęcia takiego skapitalizowanego przyszłego świadczenia jako składnika aktywów. Według polskich zasad rachunkowości podstawowa przeszkoda do ujęcia przyszłych świadczeń osobistych wspólnika do aktywów jest brak kontroli spółki nad tym składnikiem aktywów. Problem kontroli nad aktywami niematerialnymi został szeroko ujęty w Międzynarodowych Standardach Sprawozdawczości Finansowej (MSR), szczególnie w MSR 38 „Wartości niematerialne”. W zapisach tego MSR szczególnie uregulowano aktywa w postaci umiejętności i doświadczenia pracowników: „Zwykle jednak kontrola jednostki nad oczekiwanymi przyszłymi korzyściami ekonomicznymi wynikajacymi z zatrudniania grupy wykwalifikowanych pracowników i ich szkolenia jest niewystarczająca, aby móc uznać, że pozycje te spetniaja kryteria definicji składnika wartości niematerialnych. $Z$ podobnej przyczyny nie jest prawdopodobne, aby konkretne talenty kierownicze i kompetencje techniczne pracowników spełniły kryteria definicji składnika wartości niematerialnych, chyba że wykorzystywanie i pozyskiwanie oczekiwanych z tego tytułu przyszłych korzyści ekonomicznych jest prawnie chronione, a także spetnione zostaly wymogi zawarte w pozostałych częściach definicji”. Z przytoczonych zapisów MSR wynika, że niemożliwe jest ujęcie jako aktywów oczekiwanych przyszłych korzyści ekonomicznych z pracy. Jeśli zatem nie można tego typu nakładów kwalifikować jako aktywa spółki, ujęcie ich jako składnik kapitałów jest niemożliwe. Ponadto w świetle definicji rzeczowych aktywów obrotowych, świadczenie pracy przez wspólnika nie stanowi zasobu majątkowego. Mimo że oznacza dla spótki pewną korzyść ekonomiczną, to nie można takiego wkładu uznać za składnik majątku spółki. Doktryna prawa bilansowego wskazuje, że wykonanie przez wspólnika przyszłych świadczeń na rzecz spółki nie zalicza się do kategorii aktywów (A. Helin, A. Bernaziuk, R. Kowalski, Kapitały własne w świetle prawa handlowego, bilansowego i podatkowego w różnych formach działalności gospodarczej, Warszawa 2006, s. 90). Tożsame stanowisko (także na gruncie opodatkowania zmiany umowy spótki w sytuacji wniesienia wkładu w postaci świadczenia pracy przez wspólnika), wyrażone zostało w interpretacjach: Dyrektora Izby Skarbowej w Poznaniu $z 2$ maja 2013 r. 
(ILPB2/436-26/13-2/MK), Dyrektora Izby Skarbowej $w$ Katowicach $z 3$ marca 2010 r. (IBPBII/1/436-318/09/MZ) i Ministra Finansów z 4 lipca 2008 r. (PL/ LM/830/8/CHI/08/PK-411).

Projektodawca dostrzega, że w praktyce obrotu uwzględnia się w bilansie spółki jawnej wkład w postaci świadczenia pracy bądź usług na podstawie wartości tego wkładu określonego w umowie spółki. Taka interpretacja jest możliwa dzięki art. 25 pkt 2 k.s.h., który nakazuje określić w umowie spółki jawnej wartość wkładów wniesionych do spółki jawnej. Rozwiązanie to może być stosowane także w odniesieniu do innych spółek osobowych. Analogicznej regulacji nie przewidują jednak projektowane przepisy o PSA, czego projektodawca nie wyjaśnia.

4. Wskazana analiza dowodzi, że dopuszczenie wkładu w postaci pracy lub usług jest skomplikowanym problemem prawnym, który dotyczy przecież także spółki z o.o. Projektodawca nie przedstawił jednak żadnej analizy alternatywnych sposobów osiągnięcia celu w postaci uwzględnienia umiejętności pomysłodawców startupów w podziale zysków spółki i we wpływie na decyzje podejmowane w spółce. Takich alternatywnych możliwości jest wiele (np. bezpośrednie i pośrednie formy uprzywilejowania osób wnoszących do spółki szczególne umiejętności, koncepcja wkładu niepieniężnego w postaci know-how, programy motywacyjne w postaci różnych odmian opcji na akcje, akcje wirtualne, uprzywilejowane akcje założycielskie). Ewentualna dyskusja nad wprowadzeniem wkładów w postaci pracy lub usług (a w praktyce umiejętności) do spółki kapitałowej (nie przesądzając jej wyniku) może i powinna odbywać się w ramach reformy spółki z o.o. Nie wymaga to tworzenia nowego typu spółki kapitałowej.

\section{Dematerializacja}

Nową konstrukcją w projekcie są przepisy o dematerializacji akcji. Problem dematerializacji akcji nie jest specyficzny dla PSA. Dematerializacja udziałów w spółce z o.o. obowiązuje od początków istnienia tej formy spółki handlowej. Dematerializacja jest cechą spółek publicznych w praktyce od powstania w Polsce w latach 90. rynku kapitałowego. Projekt dematerializacji akcji został zaproponowany w pracach prowadzonych jeszcze w latach 2014-2015 przez Komisję Kodyfikacyjną Prawa Cywilnego i kontynuowanych pod auspicjami Ministerstwa Sprawiedliwości. Wedle wiedzy autora opinii został on już skierowany na ścieżkę legislacyjną. Niepokoi, że istnieje ryzyko współistnienia dwóch niezależnych systemów dematerializacji akcji (a de facto trzech) w Kodeksie spółek handlowych (uproszczony w spółce z o.o. w odniesieniu do udziałów, w PSA i spółce akcyjnej).

\section{Indywidualne uprawnienia kontrolne i informacyjne akcjonariuszy}

1. Projekt PSA wprowadza model indywidualnej kontroli akcjonariuszy nad spółką (art. $300^{24}$ ) wzorowany na modelu w spółce z o.o. i zawierający odesłanie do art. 212 k.s.h., który ma być stosowany odpowiednio. Jednocześnie projekt zawiera model prawa akcjonariuszy do żądania informacji o spółce oparty na 
modelu prawa do informacji każdego akcjonariusza w spółce akcyjnej (art. 3009) i odsyłający w tym zakresie do art. 428 i 429 k.s.h., które stosuje się odpowiednio.

2. Projekt nie wyjaśnia jednak, dlaczego w PSA muszą funkcjonować ze sobą dwa modele bezpośredniej kontroli akcjonariusza nad spółką, które wychodzą z całkowicie odmiennych założeń. Założeniem modelu w spółce $\mathrm{z}$ o.o. jest aktywna rola wspólnika jako właściciela spółki, który pełni funkcje nadzorcze bezpośrednio. Natomiast w modelu spółki akcyjnej jako wehikułu przeznaczonego do pozyskiwania kapitału zakłada się masowość akcjonariatu, co wyklucza indywidualną kontrolę nad spółką w obawie przed destabilizacją prowadzenia jej spraw. Odpowiednikiem indywidualnej kontroli wspólnika spółki z o.o. nad spółką jest instytucja rady nadzorczej w spółce akcyjnej. Projektowane rozwiązania stanowią ilustrację, iż projektodawca, projektując przepisy o PSA bez pogłębionej analizy, dokonywał w sposób automatyczny łączenia w ramach PSA rozwiązań charakterystycznych dla spółki z o.o. i spółki akcyjnej. Nie ulega wątpliwości, że zastosowany zabieg stwarza ryzyko odczytywania natury PSA jako spółki ciążącej w kierunku natury spółki akcyjnej z konsekwencjami w zakresie zawężenia swobody kształtowania postanowień umowy spółki PSA i faktycznej swobody odstępstw od przepisów o PSA formalnie mających status przepisów dyspozytywnych.

\section{Struktura organizacyjna spółki}

1. Jedyną funkcją przepisów projektu o strukturze organizacji PSA (art. $300^{51}$ i $300^{78}$ ) jest wprowadzenie do PSA modelu monistycznego i dualistycznego zarządzania i nadzoru nad PSA (w rzeczywistości jest to bardzo uproszczone ujęcie, ponieważ w żadnym systemie prawa spółek nie istnieje „czysty” model monistyczny i „czysty” model dualistyczny zarządzania i nadzoru nad spółką). Koncepcja ta jest obarczona błędem podstawowym wynikającym najwyraźniej z braku dostrzeżenia przez projektodawcę, iż rozbudowany model monistyczny i dualistyczny sprawowania zarządu i nadzoru nad spółką jest cechą wyróżniającą spółkę akcyjną z masowym i rozdrobnionym akcjonariatem, a także - w okresie późniejszym - spółki akcyjne prowadzące działalność $\mathrm{w}$ sektorze regulowanym (np. banki, ubezpieczyciele, towarzystwa inwestycyjne, w tym emerytalne i inne instytucje finansowe).

2. Syntetycznie rzecz ujmując, wynika on z konieczności wprowadzenia do spółki akcyjnej „protezy” właściciela, a więc mechanizmu aktywnego nadzoru właścicielskiego nad sprawowaniem zarządu w spółce. W spółce z o.o. problem ten nie występuje, ponieważ - tak jak w każdej spółce zamkniętej (o ograniczonej liczbie udziałowców) - mechanizm aktywnej kontroli właścicielskiej zapewnia instytucja prawa udziałowca do sprawowania indywidualnej kontroli nad spółką (np. art. 212 k.s.h w spółce z o.o.). Problem ten występuje w spółkach akcyjnych, które pozyskują kapitał od masowego dawcy kapitału (spółki publiczne oraz instytucje finansowe), który de facto staje się wierzycielem spółki, a nie jej udziałowcem. Istnieje zatem potrzeba regulacyjna zapewnienia mechanizmu 
kontroli właścicielskiej lub quasi-właścicielskiej sposobu zarządzania przez zarząd środkami powierzonymi spółce. Potrzeba regulacji zwiększającej elastyczność mechanizmów nadzoru właścicielskiego nad zarządem powstaje zatem, ale w spółce akcyjnej. W przepisach o spółce akcyjnej powinny być zawarte wzorcowe rozwiązania $\mathrm{w}$ tym zakresie. Tworzenie takich rozwiązań dla startupów w PSA (biorąc pod uwagę dane ekonomiczne charakteryzujące startupy opisane w niniejszej opinii) stanowi rażący przykład destabilizowania polskiego prawa spółek i tworzenia regulacji kodeksowej rozsadzającej systemowe podejście do kodeksu. Nie zostało także udowodnione, dlaczego taka rozbudowana regulacja, która nie sprzyja postulatowi uproszczenia formy spółki akcyjnej, stanowi istotną barierę dla rozwoju startupów w Polsce.

\section{Podsumowanie}

- Nie istnieje potrzeba wprowadzenia do Kodeksu spółek handlowych nowego typu spółki kapitałowej pod nazwą prosta spółka akcyjna. Cele wskazywane przez projektodawcę mogą być osiągnięte w wyniku nieskomplikowanej reformy spółki z o.o.

- Wskazywane przez projektodawcę bariery rozwoju tzw. startupów są błahe, skoro dotyczą takich kwestii, jak wartość nominalna udziału w spółce z o.o. wynosząca 50 zł, wymogu zachowania formy szczególnej przy zbywaniu udziałów spółki z o.o. oraz brak możliwości tworzenia udziałów niemych. Wprowadzanie do Kodeksu spółek handlowych nowego typu spółki dla pokonania tych „barier” świadczy wręcz o braku powagi uzasadnienia w zakresie podstawowym, jakim jest uzasadnienie potrzeby i celu regulacji.

- Argument, że spółka akcyjna nie spełnia potrzeb startupów, dowodzi niezrozumienia przez projektodawcę, iż spółka akcyjna z natury jest przeznaczona do prowadzenia działalności wielkich rozmiarów i pozyskiwania kapitału na rynku publicznym oraz na rynku sektorów regulowanych (instytucje finansowe). Wskazane w uzasadnieniu opinii badania PARP i Fundacji StartUp Poland dowodzą, że startupy należą do kategorii mikroprzedsiębiorców o bardzo niskim wskaźniku przeżywalności oraz o bardzo wysokim ryzyku.

- Projekt wprowadza liczne rozwiązania w oderwaniu od rozwiązań funkcjonujących w spółce z o.o. i spółce akcyjnej w sposób prowadzący do destabilizacji i rozsadzenia systemu prawa spółek kapitałowych. Regulacja prostej spółki akcyjnej staje się swoistym „państwem“ w „państwie prawa spółek kapitałowych“, nie zawierając przy tym żadnych oryginalnych rozwiązań, które nie byłyby znane lub nie byłyby dyskutowane od dziesięcioleci w prawie spółek.

- Projektodawca przyjął metodę stworzenia konstrukcji prostej spółki akcyjnej jako swoistego zlepku rozwiązań znanych spółce z o.o., spółce akcyjnej, spółkom osobowym oraz spółce europejskiej. 
- Projekt doprowadza do sytuacji, w której bez uzasadnienia merytorycznego mamy zróżnicowane rozwiązania przyjmowane w tych samych kwestiach w prostej spółce akcyjnej oraz w spółce $\mathrm{z}$ o.o. i spółce akcyjnej. Proponuje się, aby w PSA można było wnieść wkład w postaci usługi; wprowadzić business judgement rule; obowiązek lojalności; monistyczny model zarządzania (który demonizuje się); test wypłacalności; uproszczoną likwidację; swobodę uprzywilejowania akcji; zrezygnować z kapitału zakładowego i wprowadzić akcje beznominałowe. - Projekt PSA liczy 133 artykuły podzielone na paragrafy, a do tego odesłania, a więc łącznie prawdopodobnie ponad 200 przepisów. Jest regulacją obszerniejszą i bardziej skomplikowana niż regulacja dotycząca spółki z o.o., spółki akcyjnej i spółki komandytowo-akcyjnej. Jest zlepkiem tych spółek. Fundacja Startup Poland apelowała: prosta spółka akcyjna ma być rzeczywiście prosta. Sama idea [...] spółki kapitałowej ułatwiającej rozwój przedsięwzięcia opartego na innowacjach oceniana jest pozytywnie, ale towarzysza jej obawy zbytniego przeregulowania i stworzenia "hybrydy” prawnej. Miejmy nadzieje, że dzięki naszej wspólnej pracy uda się temu zapobiec i PSA faktycznie będzie odpowiedzia na problemy ograniczajace rozwój startupów w Polsce [...]. Lansowana teza, iż nie liczba przepisów świadczy o prostocie regulacji prawnych, nie wymaga zgodnie z doświadczeniem życiowym polemiki. Liczba przepisów, hybrydowy charakter PSA, liczne odesłania, nieznane dotychczasowemu prawu spółek konstrukcje jak udziały beznominałowe, wprowadzenie instytucji prawnych w PSA bez uzasadnienia ich braku w spółce z o.o. i spółce akcyjnej (np. zasada business judgement rule), dualizm rozwiązań prawnych dotyczących tych samych instytucji w PSA i innych spółkach kapitałowych (np. kadencja, mandat, prawa i obowiązki zarządu oraz rady nadzorczej, zasady odpowiedzialności, ochrona wierzycieli, wyłączania akcjonariusza ze spółki, sposoby podwyższania kapitału zakładowego) stwarzają bardzo wysokie ryzyko nie tylko poważnych trudności w stosowaniu przepisów o PSA, ale także w stosowaniu przepisów o spółce z o.o. i spółce akcyjnej. Projekt PSA $w$ istocie zrywa bowiem $z$ dotychczasową zasadę autonomii regulacji spółki z o.o. i spółki akcyjnej ograniczającej metodę wykładni uzupełniania rzeczywistych i „rzekomych” luk w prawie, $w$ tym przy zastosowaniu wnioskowań typu a simili, a contrario, wykładni zwężającej, wykładni rozszerzającej.

- Projekt PSA stwarza wysokie ryzyko upodobnienia prawa spółek do prawa podatkowego, które jest niespójne z powodu wielości i braku spójności przepisów.

- Podzielam konkluzję na temat potrzeby wprowadzenia PSA do Kodeksu spółek handlowych i jego szczegółowych rozwiązań sformułowaną w opinii Rady Legislacyjnej przy premierze przyjętej na posiedzeniu Rady Legislacyjnej w dniu 22 czerwca 2018 r. Konkluzja Rady Legislacyjnej była następująca: projekt nowelizacji k.s.h. [...] wprowadzający prostą spółkę akcyjna rodzi tak duża ilość wątpliwości i zastrzeżeń, iż w tym kształcie winien zostać skierowany do dalszych prac analitycznych przy udziale środowiska naukowego. Wprowadzenie tego projektu może bowiem godzić $w$ bezpieczeństwo obrotu prawnego przez faktyczne wpro- 
wadzenie do prawa polskiego zamiast prostej spółki akcyjnej tzw. „spółki akcyjnej bis” czy „spółki akcyjnej light”. Projektowana regulacja nie uwzględnia przepisów dotyczacych pozostałych spółek kapitałowych, co przejawia się m.in. w tworzeniu własnej siatki pojęciowej. Wywoła to z kolei fundamentalne trudności interpretacyjne na gruncie istniejacych regulacji [...]. Tym samym przedłożony do zaopiniowania projekt $w$ istocie swej nie spełni zasadniczego celu, jaki został sformułowany w uzasadnieniu, a polegający a ukształtowaniu „nowoczesnej spółki niepublicznej dla nowoczesnej gospodarki”, a w szczególności spółki przeznaczonej do realizacji nowych przedsięwzięć podejmowanych $w$ warunkach dużej niepewności rynkowej, czyli tzw. startupów.

- Moje ponad 25-letnie doświadczenie akademika i praktyka, a także ponad 12-letnie doświadczenie legislacyjne, w tym przez 10 lat jako członka Komisji Kodyfikacyjnej Prawa Cywilnego upoważnia mnie do sformułowania prognozy, że orzecznictwo i doktryna będzie przez wiele lat debatowała nad naturą PSA w odniesieniu do natury spółki z o.o. i spółki akcyjnej oraz że należy liczyć się z wysokim ryzykiem uznania, iż za standard odejścia od zasady jedna akcja - jeden głos zostanie przyjęty standard obowiązujący w spółce akcyjnej jako spółce, do której prosta spółka akcyjna ciąży najbardziej. Prowadzi to do wniosku, że niezależnie od deklaracji projektodawcy, odpowiedzialny doradca prawny będzie musiał uprzedzić klientów, iż istnieje wysokie ryzyko, że przywileje przyznawane akcjonariuszom w PSA odbiegające lub znacznie odbiegające od przywilejów dopuszczalnych w spółce akcyjnej zostaną uznane przez sądy za sprzeczne z naturą spółki kapitałowej, w tym PSA, a więc nieważne.

- Metoda wolności kształtowania umowy PSA została oparta na modelu analogicznym do spółki z o.o., a więc poprzez wyraźne wskazywanie w konkretnych przepisach, że umowa spółki PSA może zawierać rozwiązania odmienne, ale w granicach określonych naturą spółki, zasadami współżycia społecznego i przepisami prawa. W modelu wzorca kompetencji szczególnej jako wyznacznika treści swobody kształtowania umów strony w praktyce w znacznie większym stopniu ograniczone są szczegółowymi przepisami dyspozytywnymi, które stanowią naturalny (w modelu numerus clausus umów spółek handlowych) punkt odniesienia dla wypełniania treścią zasad współżycia społecznego i natury umowy jako stosunku prawnego. Owa większa swoboda przy kształtowaniu umowy spółki PSA może okazać się zatem iluzoryczna, a z pewnością jest obarczona dużym ryzykiem niepewności. Co do rzeczywistego zakresu swobody kształtowania umowy PSA pewna jest ... niepewność.

\section{Bibliografia}

Helin A., Bernaziuk A., Kowalski R., Kapitały własne w świetle prawa handlowego, bilansowego i podatkowego w różnych formach działalności gospodarczej, Warszawa 2006. 
Kępiński M., Seweryński M., Zieliński A., Rola kodyfikacji na przykładzie prawa prywatnego w procesie legislacyjnym, „Przegląd Legislacyjny” 2006, nr 1.

Kudej M., Postępowania ustawodawcze w Sejmie RP, Warszawa 2002.

Rada Legislacyjna przy Prezesie Rady Ministrów, Tworzenie prawa w Polsce - ocena i proponowane kierunki zmian. Raport, Listopad 2005, „Przegląd Legislacyjny” 2006, nr 1.

Romanowski M. [w:] System prawa prywatnego, t. XVI, Prawo spółek osobowych, red. A. Szajkowski, Warszawa 2016.

Rot H., Kształtowanie systemu prawa. Więź pozioma systemu prawa, t. III, Wrocław 1984. Weitz K., Czy nowa kodyfikacja postępowania cywilnego?, „Państwo i Prawo” 2007, z. 3.

Wronkowska S., W sprawie postępowania legislacyjnego w przepisach Regulaminu Sejmu Rzeczypospolitej Polskiej, „Przegląd Sejmowy” 2000, nr 2. 